\title{
Characterisation of the bacterial microbiota of the vagina of dairy cows and isolation of pediocin- producing Pediococcus acidilactici
}

\author{
Yvonne Wang ${ }^{1}$, Burim N Ametaj ${ }^{1}$, Divakar J Ambrose ${ }^{1,2}$ and Michael G Gänzle ${ }^{1 *}$
}

\begin{abstract}
Background: Uterine infections in dairy cows lower profitability of dairy operations. Infections of the reproductive tract are related to the overgrowth of pathogenic bacteria during the first three weeks after parturition. However, alterations in the vaginal microbiota composition in the first weeks after parturition remain poorly documented.

Results: In this study, bacteria isolated from the vagina of healthy pregnant, and infected postpartum cows were characterised by random amplification of polymorphic DNA (RAPD) analysis and partial 165 ribosomal RNA (rDNA) gene sequencing. Populations of bacilli and lactic acid bacteria of the genera Enterococcus, Lactobacillus, and Pediococcus were present in both healthy and infected cows. Infected cows had a significant increase in the vaginal enteric bacteria population which consisted mainly of Escherichia coli. Three E. coli isolates harboured the gene coding for Shiga-like-toxin (SLT) I or II. Several isolates of the Pediococcus acidilactici were found to produce the bacteriocin pediocin AcH/PA-1. Quantitative PCR analyses of vaginal mucus samples collected from ten metritic cows before and after parturition confirmed the presence of the Lactobacillus group (Lactobacillus spp., Pediococcus spp., Leuconostoc spp., and Weissella spp.); Enterobacteriaceae, E. coli, and bacilli. The presence of the pediocin AcH/PA-1 structural gene and SLT genes were also confirmed with qPCR.
\end{abstract}

Conclusions: In conclusion, overgrowth of pathogenic bacteria, particularly E. coli, after parturition likely contributes to the development of metritis. Our microbiota analysis extends the information related to the composition of commensal bacteria in the bovine female reproductive tract and may facilitate the development of novel intervention strategies for prevention of uterine infections in dairy cows.

Keywords: Lactic acid bacteria, Dairy cow, Metritis, Pediocin PA-1/AcH, Shiga-like toxin

\section{Background}

Infection of the uterus has a significant impact on the profitability of the dairy industry because of lowered reproductive efficiency, decreased milk production, and increased costs associated with treatment and culling of animals due to infertility [1-3]. Uterine infections in dairy cows are associated with predisposing factors including calving difficulty, retained placenta, compromised immune status and parity, along with the overgrowth of pathogenic microorganisms in the reproductive tract [4]. Immediately after calving, the dilated state of the cervix allows microorganisms from the

\footnotetext{
* Correspondence: mgaenzle@ualberta.ca

${ }^{1}$ Department of Agricultural, University of Alberta, Food and Nutritional

Science, 4-10 Ag/For Centre, Edmonton, AB T6G 2P5, Canada

Full list of author information is available at the end of the article
}

environment, cow's skin, and fecal material to enter through the vagina into the uterus and initiate inflammation of the endometrium, which is highly associated with infertility [5]. Metritis associated bacteria have been classified as pathogens, potential pathogens, or opportunistic pathogens [6,7]. Recognised uterine pathogens that are associated with severe endometrial inflammation and clinical endometritis include Escherichia coli, Arcanobacterium pyogenes, Fusobacterium necrophorum, Prevotella melaninogenica and Proteus species [6,7]. Williams et al. [8] considered high cell counts of E. coli as the basis for the onset of uterine infection.

In a healthy female reproductive tract of humans, mice, or monkeys, lactobacilli are among the predominant organisms [9-11]. Vaginal lactobacilli inhibit the growth of genitourinary pathogenic micro-organisms 
through mechanisms of competitive exclusion of pathogens, stimulation of the host immune system, and production of specific antibacterial compounds such as acetic and lactic acids, hydrogen peroxide, and antimicrobial peptides [12,13]. A contribution of bacteriocin production by vaginal probiotics to probiotic activity has not been demonstrated experimentally, but formation of the bacteriocin Abp118 by Lactobacillus salivarius UC118 conferred resistance to infection by Listeria monocytogenes in mice [14].

The microbial flora of a healthy bovine reproductive tract consists of a combination of aerobic, facultatively anaerobic, and obligately anaerobic microorganisms. Lactobacilli were found to be present in low numbers in the bovine vaginal microbiota [15]; additionally, Enterobacteriaceae are among the dominant populations [16]. However, alterations in the vaginal microbiota composition in the first weeks after parturition, i.e. the time during which metritis develops, remain poorly documented. The aim of our study is to characterize the vaginal microbiota of both healthy pregnant and infected post-partum cows by culturedependent analysis. In addition, retrospective culture independent quantitative PCR (qPCR) analysis was used to characterize the vaginal microbiota of metritic cows two weeks before and two weeks calving. Isolates were studied with regards to Shiga-like toxin and pediocin production.

\section{Results}

\section{Composition of microbiota in healthy and infected dairy} cows: Isolation and identification of bacterial species

Analysis of the microbiota of the reproductive tract of dairy cows was initially based on a qualitative, culturedependent approach. Bacterial isolates were obtained from healthy, pre-partum animals $(n=7)$ or metritic, post-partum animals $(n=8)$. Clonal isolates were eliminated by RAPD-PCR analysis and isolates differing in their origin, RAPD profile, or colony morphology were identified on the basis of the sequence of approximately $1400 \mathrm{bp}$ of the $16 \mathrm{~S}$ rRNA genes. Strain identification to species level was based on $97 \%$ or greater sequence homology to type strains. Strains of the species E. coli could not be identified on the basis of $16 \mathrm{~S}$ rRNA sequences alone because of the high homology of rDNA sequences to closely-related species such as Shigella spp. and Escherichia fergusonii. Classification of all E. coli strains was verified with species-specific PCR and API$20 \mathrm{E}$ test strips. The biochemical characteristics of isolates matched properties of E. coli $(99.8 \%)$ in the API$20 \mathrm{E}$ database. The identity of thirty isolates and their origin is listed in Table 1.

Bacilli, staphylococci, and lactic acid bacteria of the genera Enterococcus, Lactobacillus, and Pediococcus were present in both healthy and infected cows. Escherichia coli were also frequently isolated, particularly from infected animals. Isolates were screened for the presence of SLT-I and SLT-II genes, sample results for their PCR detection in $E$. coli isolates are shown in Figure 1a and Figure 1b, respectively. E. coli FUA1064 isolated from cow \#2507 harboured the SLT-I gene, while E. coli FUA1037 and FUA1062, isolated from cow \#2373 and \#2374, respectively harboured the SLT-II gene (Table 1).

\section{Pediocin production}

PCR screening revealed that Ped. acidilactici FUA3137, FUA3140, and FUA3138 harboured the pediocin AcH/ PA-1 immunity gene (Table 1 ). Pediocin production was investigated for selected isolates via deferred inhibition assays. Ped. acidilactici FUA3138 and FUA3140 produced inhibition zones against Enterococcus faecalis FUA3141 (Figure 2a). Inhibition zones of comparable diameter were observed with L. innocua (data not shown). Further tests with proteinase $\mathrm{K}$ verified that the antimicrobial agent is a protein (Figure $2 \mathrm{~b}$ ). Other vaginal isolates including $E$. coli FUA1036, FUA1063, and FUA1064 were also used as indicator strains but no inhibition was observed (data not shown).

\section{Quantification of bacterial groups, SLT and pediocin structural genes}

The DNA concentration of most samples did not allow amplification with HDA primers; PCR products could be obtained only for two samples (data not shown). Sequencing of the PCR products from these animals (\#2373 and \#2409) confirmed that bacteria present in the bovine vagina of these two animals were accounted for by culturing (data not shown). Subsequently, quantitative PCR was employed as sensitive and quantitative tool for cultureindependent analysis of the composition of vaginal microbiota before and after parturition. Primers were selected to quantify bacterial groups isolated from healthy, prepartum or postpartum animals, as well as SLT genes and the pediocin structural gene (pedA) (Table 1). Fourty animals were sampled two weeks pre-partum and two weeks post-partum; of these, ten animals that developed metritis post-partum were selected for DNA isolation and analysis by qPCR. To account for the large individual differences in the vaginal microbiota of different animals, results were calculated as differences (post-partum - pre-partum) between the least square means of log rDNA or DNA copy numbers for each target group (Figure 3). Copy number of 16S rDNA from Enterococcus spp. and Staphylococcus spp. were below the detection limit of $10^{2}$ copy numbers / $\mathrm{g}$ (data not shown). The number of rDNA copies of the Lactobacillus group was relatively stable in the observation period. In all other cases, the postpartum gene copy values are higher than the prepartum values. The pediocin structural gene was consistently detected in low numbers. Approximately a $3 \mathrm{log}$ difference between the total 
Table 1 Qualitative characterization of the vaginal microbiota of dairy cows

\begin{tabular}{|c|c|c|c|c|c|}
\hline Animal \# & FUA \# & Identified Species & \% Identity to Type Strain ${ }^{\text {(a) }}$ & Shiga -like Toxin Gene & Pediocin Immunity Gene \\
\hline \multirow[t]{4}{*}{2102 (Healthy) } & 3086 & Staphylococcus epidermidis & 0.990 & n.d. & n.d. \\
\hline & 3087 & Staphylococcus epidermidis & 0.991 & n.d. & n.d. \\
\hline & 3088 & Staphylococcus warneri & 0.985 & n.d. & n.d. \\
\hline & 3089 & Lactobacillus sakei & 0.986 & n.d. & n.d. \\
\hline 2151 (Healthy) & 1167 & Proteus mirabilis & 0.995 & n.d. & n.d. \\
\hline \multirow[t]{6}{*}{2363 (Healthy) } & 1035 & Escherichia coli & 0.980 (Shigella flexneri) & - & n.d. \\
\hline & 1037 & Escherichia coli & 0.930 & SLT-II & n.d. \\
\hline & 3137 & Pediococcus acidilactici & 0.990 & n.d. & + \\
\hline & 3140 & Pediococcus acidilactici & 1.000 & n.d. & + \\
\hline & 3141 & Enterococcus faecalis & 0.990 & n.d. & n.d. \\
\hline & 3226 & Pediococcus acidilactici & 0.990 & n.d. & - \\
\hline 2367 (Healthy) & 3136 & Staphylococcus warneri & 0.993 & n.d. & n.d. \\
\hline \multirow[t]{4}{*}{2374 (Healthy) } & 1062 & Escherichia coli & 0.976 (Shigella flexneri) & SLT-II & n.d. \\
\hline & 2027 & Bacillus licheniformis & 0.982 & n.d. & n.d. \\
\hline & 2028 & Bacillus licheniformis & 0.978 & n.d. & n.d. \\
\hline & 3251 & Streptococcus pluranimalium & 0.990 & n.d. & n.d. \\
\hline \multirow[t]{2}{*}{2409 (Healthy) } & 1046 & Escherichia coli & 0.978 (Shigella flexneri) & - & n.d. \\
\hline & 3135 & Staphylococcus hominis subsp. hominis & 0.991 & n.d. & n.d. \\
\hline \multirow[t]{2}{*}{2426 (Healthy) } & 2023 & Bacillus altitudinis & 0.998 & n.d. & n.d. \\
\hline & 2024 & Bacillus pumilus & 0.981 & n.d. & n.d. \\
\hline \multirow{2}{*}{$\begin{array}{l}\text { *2211-A } \\
\text { (Infected) }\end{array}$} & 1036 & Escherichia coli & 0.981 (Shigella flexneri) & - & n.d. \\
\hline & 3139 & Enterococcus faecalis & 0.980 & n.d. & n.d. \\
\hline \multirow[t]{6}{*}{ *2211-B (Infected) } & 1174 & Escherichia coli & 0.980 & - & n.d. \\
\hline & 1176 & Escherichia coli & 0.980 & - & n.d. \\
\hline & 2044 & Bacillus licheniformis & 0.998 & n.d. & n.d. \\
\hline & 2045 & Bacillus galactosidilyticus & 0.990 & n.d. & n.d. \\
\hline & 2049 & Bacillus oleronius & 0.990 & n.d. & n.d. \\
\hline & 2052 & Rummeliibacillus pycnus & 0.970 & n.d. & n.d. \\
\hline \multirow[t]{6}{*}{2312 (Infected) } & 2039 & Bacillus licheniformis & 0.982 & n.d. & n.d. \\
\hline & 2047 & Lysinibacillus fusiformis & 0.970 & n.d. & n.d. \\
\hline & 2048 & Sporosarcina contaminans & 0.980 & n.d. & n.d. \\
\hline & 2050 & Streptococcus thoraltensis & 0.990 & n.d. & n.d. \\
\hline & 2051 & Rummeliibacillus pycnus & 0.970 & n.d. & n.d. \\
\hline & 3308 & Lactobacillus mucosae & 0.996 & n.d. & n.d. \\
\hline 2373 (Infected) & 1063 & Escherichia coli & $\begin{array}{l}0.987 \text { (Shigella flexneri / } \\
\text { Escherichia fergusonii) }\end{array}$ & - & n.d. \\
\hline \multirow[t]{2}{*}{2429 (Infected) } & 3227 & Staphylococcus warneri & 0.990 & n.d. & n.d. \\
\hline & 3138 & Pediococcus acidilactici & 0.990 & n.d. & + \\
\hline 2435 (Infected) & 1049 & Escherichia coli & $\begin{array}{l}0.980 \text { (Shigella flexneri / } \\
\text { Escherichia fergusonii) }\end{array}$ & - & n.d. \\
\hline 2436 (Infected) & 1070 & Escherichia coli & 0.973 (Escherichia fergusonii) & - & n.d. \\
\hline \multirow[t]{3}{*}{2507 (Infected) } & 1064 & Escherichia coli & 0.960 (Shigella flexneri) & SLT-I & n.d. \\
\hline & 3180 & Streptococcus pluranimalium & 0.990 & n.d. & n.d. \\
\hline & 2029 & Bacillus licheniformis & 0.995 & n.d. & n.d. \\
\hline
\end{tabular}

(a) \% identity of partial $16 \mathrm{~S}$ rDNA to type strain or closest relative; +: positive PCR results; -: negative PCR results; n.d.: data not determined. ${ }^{*}$ Cow \#2211-A and 2211-B represent two different animals that were assigned the same number at different times.

Healthy, pregnant animals and those diagnosed with post partum uterine infections at the time of sampling are indicated in brackets. 


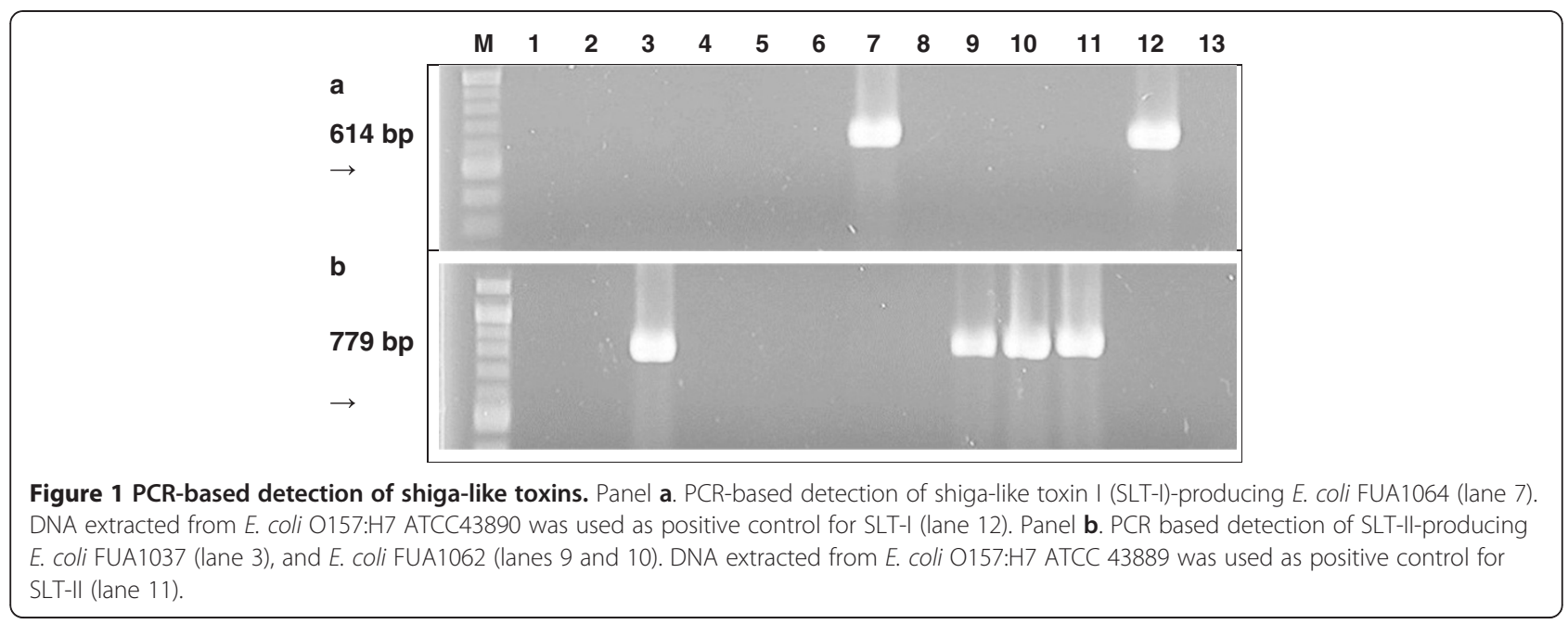

bacteria values was observed. This increase was predominantly attributable to increased numbers of $E$. coli and Enterobacteriaceae. E. coli increased on average by more than $3 \mathrm{log}$. Genes coding for SLT-I and SLT-II increased by less than $2 \log$.

\section{Discussion}

This study provides a comparison of the vaginal microbiota of healthy, pregnant dairy cows, and infected postpartum cows. In contrast to the stable commensal microbiota observed in humans and other mammals [9-11], total bacterial numbers in vaginal mucus were low and the composition of the bovine vaginal microbiota on species level was highly variable. Bacteria found within the microbiota are thus likely to be contaminants from the environment (Bacillus spp.), the cow's skin (Staphylococcus spp.), or faecal material (E. coli, lactic acid bacteria), rather than representing a stable flora autochthonous to the reproductive tract. The lack of a competitive commensal vaginal microbiota may contribute to the susceptibility of dairy cows to bacterial overgrowth and metritis after parturition [8,17]. Indeed, quantitative PCR demonstrated a substantial increase of bacterial numbers, particularly of Enterobacteriaceae and E. coli, in infected cows after parturition compared to samples from the same animals obtained pre-partum.

Overall, our data indicated that vaginal bacterial flora in cows affected by metritis was dominated by strains of E. coli, supporting previous observations [17]. This study extends previous results $[15,16]$ by documenting changes of the vaginal microbiota in individual animals in the first two weeks after calving. Both the Enterobacteriaceae and
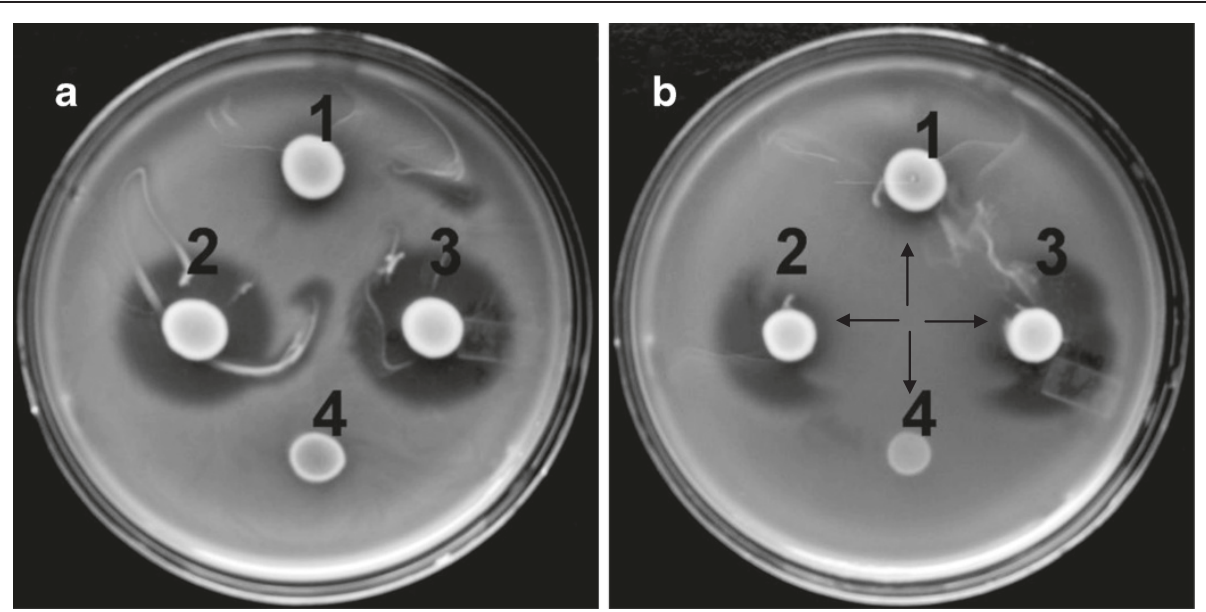

Figure 2 Deferred inhibition assay for bacteriocin production. Test strains were grown on mMRS and overlayered with Enterococcus faecalis FUA3141, which was as an indicator strain. Panel $\mathbf{a}$, no addition of proteinase; panel $\mathbf{b}$, addition of proteinase $\mathrm{K}$ adjacent to colonies of test strains. Arrows indicate the site of proteinase K application. The following test strains were used, 1, Ped. acidilactici FUA3138; 2, Ped. acidilactici FUA3072; 3, Ped. acidilactici FUA3140; 4, Lact. sakei FUA3089. Similar results were observed with Listeria innocua ATCC33090 used as an indicator strain (data not shown). The indicator strains of E. coli FUA1036, FUA1063 and FUA1064 were also used but no inhibition was observed (data not shown). 


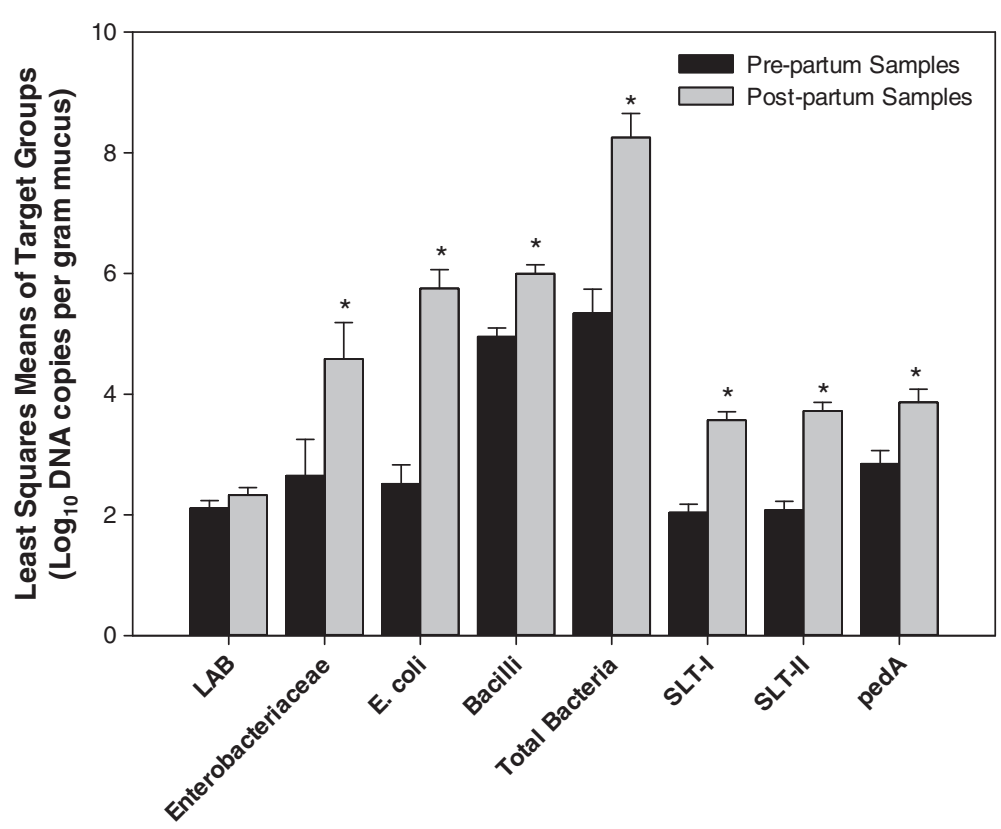

Figure 3 Differences in least squares means of log rDNA or DNA copy numbers of target groups. Vaginal mucus was sampled from ten animals before and after calving, and bacterial rDNA, shiga-like-toxin genes, and the pediocin structural gene were quantified by qPCR. The figure depicts the differences in least squares means of the target groups. Statistically significant differences between prepartum and postpartum periods were observed in all groups (as indicated by *) except for the lactic acid bacteria group.

E. coli showed marked increase in mucus samples collected from infected postpartum cows. The amplification of Shigella rDNA with E. coli species-specific primers is not surprising because Shigella spp. and E. coli are indistinguishable on the basis of rDNA sequences [18]. In keeping with the recognition of Shigella spp. as humanadapted pathovar of $E$. coli, all isolates were identified as E. coli by biochemical tests. Culture-based analysis and qPCR demonstrated presence of shiga-like-toxin producing E. coli (STEC) in both healthy and infected animals. Three out of eleven E. coli isolates were found to carry genes coding for SLT-1 or SLT-II. Moreover, SLT-genes were consistently detected by $\mathrm{qPCR}$ in samples from metritic cows; STEC accounted for about $1-10 \%$ of the total E. coli population. SLT production causes diarrhoea in calves [19], but the role of STEC in the pathogenesis of metritis in adult animals warrants further clarification.

Bacilli are present in the environment and they frequently contaminate the bovine uterine lumen [20]. However, pediococci have not yet been described as part of the bovine vaginal microbiota. The genus Pediococcus is closely related to the genus Lactobacillus. Pediococci produce antimicrobial compounds such as organic acids, hydrogen peroxide, and antimicrobial peptides such as pediocin AcH/PA-1 [21]. Ped. acidilactici is a food fermenting organism [21] but was also isolated from the gastrointestinal tract of poultry, ducks, and sheep[22-24]. Pediocin AcH/PA-1 producing strains have been isolated from human infant faeces [25].
The synthesis of pediocin AcH/PA-1 was initially described for the strains Ped. acidilactici PAC1.0 and Ped. acidilactici $\mathrm{H}$, but synthesis has also been observed in other Ped. acidilactici strains as well as Lactobacillus plantarum WHE92, Pediococcus parvulus ATO34, and ATO77 [26-28]. Pediocin AcH/PA-1 production is a plasmid-borne trait [29]. The pediocin AcH/PA-1 operon consists of pediocin AcH/PA-1 gene (pedA/papA), a specific immunity gene ( $p a p B)$, and genes responsible for processing and secretion (papC and papD) [30]. In keeping with prior reports on pediocin activity [31], pediocin was not active against $E$. coli, the dominant organisms in the vaginal microbiota of infected animals. Pediocin producing isolates characterized in this study harboured the pediocin AcH/PA-1 operon, and qPCR analysis consistently detected the operon in both prepartum and postpartum vaginal samples.

Bacteriocin formation is increasingly recognized as an important trait of probiotic cultures [32]. Studies on the isolation of bacteriocin-producing lactic acid bacteria from the human vagina demonstrated their antimicrobial activities against human vaginal pathogens [33,34]. Bacteriocin-producing Lactobacillus strains inhibited vaginal pathogens including Gardnerella vaginalis and Pseudomonas aeroginosa [35]. Although bovine vaginal microbiota have much lower total cell counts and lactobacilli populations in comparison to the human vaginal microbiota $[16,36]$, bacteriocin such as pediocin may influence the microbial ecology in the reproductive tract 
of dairy cattle if bacteriocin-producing lactic acid bacteria are administered in high numbers.

\section{Conclusions}

In conclusion, culture-dependent analysis of the bacterial vaginal microbiota of dairy cows, supported by qPCR analysis, allowed the characterization of the bovine vaginal microbiota of healthy pregnant and infected postpartum cows. Identification of pediocin-producing pediococci in the bovine vaginal microbiota may allow the development of novel prophylactic interventions against metritis by application of bacteriocin-producing probiotic bacteria into the vaginal tract of dairy cows.

\section{Methods}

\section{Animals}

In a first experiment, fifteen lactating Holstein dairy cows were used to characterize the vaginal microbiota of healthy pregnant and metritic postpartum cows. In a second experiment, ten animals were selected to characterize the vaginal microbiota of metritic cows two weeks before calving and two weeks after calving. Samples from these ten animals were selected retrospectively after diagnosis of metritis among a group of 40 dairy cows. All animals were maintained at the Dairy Research and Technology Centre of the University of Alberta. Metritis or uterine infections were diagnosed on the basis of criteria established by Sheldon et al. [1]. Primarily, cows with watery reddishbrown, purulent, or mucopurulent discharges with fetid odour were considered to have metritis. Rectal temperatures of $39.5^{\circ} \mathrm{C}$ or higher and impaired general condition as expressed in a lowered feed intake or milk production were also taken into consideration for diagnosis. Ethics approval was obtained from the Animal care and Use Committee for Livestock of the Faculty of Agricultural, Life and Environmental Sciences (University of Alberta protocol \#A5070-01).

\section{Samples}

For culture-dependent analyses in experiment 1, vaginal swab samples were obtained from seven healthy pregnant cows and eight infected post-partum cows. The vulvar area was thoroughly cleaned with water and then disinfected with $30 \%$ ( $\mathrm{vol} / \mathrm{vol}$ ) iodine solution (Iosan, WestAgro, Saint Laurent, Canada) prior to sampling. A stainless steel vaginal speculum was gently inserted into the vagina, opened, and a long-handled sterile cotton swab was introduced to obtain a sample from the anterolateral vaginal wall. Each sample was collected in 4 $\mathrm{mL}$ of $0.1 \%(\mathrm{w} / \mathrm{v})$ sterile peptone water with $0.85 \%(\mathrm{w} / \mathrm{v})$ $\mathrm{NaCl}$ and $0.05 \%(\mathrm{w} / \mathrm{v})$ L-cysteine- $\mathrm{HCl} \times \mathrm{H}_{2} \mathrm{O}$. The cotton swab was moistened by immersion in the peptone water immediately before sampling. Owing to the low amount of mucus retrieved from healthy, pregnant cows, the weight of the mucus recovered was not recorded.

For culture-independent analyses in experiment 2, vaginal mucus samples were collected using syringes fitted with an approximately $30 \mathrm{~cm}$ long collection tube without the use of a vaginal speculum. The weight of mucus in each sample was determined by recording the total weight of each sample collection tube with $1 \mathrm{ml}$ of peptone water before and after each mucus sample was collected. All samples were stored at temperatures between $-20^{\circ} \mathrm{C}$ to $-80^{\circ} \mathrm{C}$.

\section{Isolation of microorganisms}

Ten-fold serially diluted samples were plated on Reinforced Clostridial Medium (RCM) with 5\% animal blood, Endo agar (Difco, Sparks, USA), and modified MRS (mMRS) agar [37]. Representative colonies from each type of plates and colony morphology were purified by repeated streak-plating until a uniform colony morphology was obtained. Isolates from mMRS and RCM with blood were streaked on mMRS agars whereas isolates from Endo plates were streaked on Luria Bertani (LB) agars. Frozen stock cultures of each isolate were prepared from a single colony and stored in $60 \%$ glycerol at $-70^{\circ} \mathrm{C}$.

\section{General molecular techniques}

General DNA manipulations and agarose gel electrophoresis were performed as described by Sambrook et al. [38]. Chromosomal DNA of isolated strains was extracted from $1 \mathrm{ml}$ cultures using a DNeasy ${ }^{\circledR}$ Blood and Tissue Kit (Qiagen, Mississauga, Canada). Unless otherwise stated, PCR amplifications were performed in GeneAmp $^{\circledR}$ PCR System 9700 (Applied Biosystems, Streetsville, Canada) by using Taq DNA polymerase and deoxynucleoside triphosphates (Invitrogen, Burlington, Canada). The PCR products were purified using the QIAquick PCR purification kit (Qiagen).

\section{Random amplified polymorphic DNA-PCR (RAPD-PCR) analysis}

RAPD typing was used to identify clonal isolates. Isolates with the same origin, the same colony morphology, and identical RAPD patterns were considered clonal isolates. DNA template was isolated as described above. DAF4 primer was used to generate RAPD patterns for isolates from Endo agar and M13V primer was used for RAPD typing of all other strains (Table 2). The reaction mixture contained $10 \mu \mathrm{L}$ of $5 \mathrm{x}$ Green GoTaq $^{\circledR}$ Reaction Buffer (Promega, San Luis Obispo, USA), $3 \mu \mathrm{L}$ of 25 $\mathrm{mM} \mathrm{MgCl} 2$ (Promega), 150 pmol primer (Table 2), $1 \mu \mathrm{L}$ of $10 \mathrm{mmol} \mathrm{L}^{-1} \mathrm{dNTP}$ (Invitrogen, Burlington, Canada), 1.5 U GoTaq ${ }^{\circledR}$ DNA Polymerase (Promega), and $1 \mu \mathrm{L}$ of template DNA suspension or autoclaved water filtered with Milli-Q water purification system as the negative 
Table 2 Primers used in the study

\begin{tabular}{|c|c|c|c|}
\hline Target/Specificity & Primer/Probe Sequence $\left(5^{\prime} \rightarrow 3^{\prime}\right)$ & $\begin{array}{l}\text { Annealing } \\
\text { Temperature }\left({ }^{\circ} \mathrm{C}\right)\end{array}$ & Reference \\
\hline \multirow{2}{*}{$\begin{array}{l}\text { +Lactobacillus -Pediococcus-Leuconostoc-Weissella } \\
\text { (Lactobacillus group) (341 bp) }\end{array}$} & Lac1: AGC AGT AGG GAA TCT TCC A & \multirow[t]{2}{*}{62} & \multirow[t]{2}{*}[39,40]{} \\
\hline & Lab667r: CAC CGC TAC ACA TGG AG & & \\
\hline \multirow[t]{2}{*}{ tEnterococcus spp.(144 bp) } & Ent-F: CCC TTA TTG TTA GTT GCC ATC ATT & \multirow[t]{2}{*}{60} & \multirow[t]{2}{*}{ [41] } \\
\hline & Ent-R: ACT CGT TGT ACT TCC CAT TGT & & \\
\hline \multirow[t]{2}{*}{ tEnterobacteriaceae (195 bp) } & Enterobac-F: CAT TGA CGT TAC CCG CAG AAG AAG C & \multirow[t]{2}{*}{63} & \multirow[t]{2}{*}{ [42] } \\
\hline & Enterobac-R: CTC TAC GAG ACT CAA GCT TGC & & \\
\hline \multirow[t]{2}{*}{ †Staphylococcus spp. (370 bp) } & TStaG422: GGC CGT GTT GAA CGT GGT CAA ATC & \multirow[t]{2}{*}{55} & \multirow[t]{2}{*}{ [43] } \\
\hline & TStaG765: TIA CCA TTI CAG TAC CTT CTG GTA A & & \\
\hline \multirow[t]{2}{*}{ †Bacillus spp. (995 bp) } & BacF: GGGAAACCGGGGCTAATACCGGAT & \multirow[t]{2}{*}{55} & \multirow[t]{2}{*}{ [44] } \\
\hline & BacR: GTC ACC TTA GAG TGC CC & & \\
\hline \multirow[t]{2}{*}{ †E. coli (544 bp) } & ECP79F: GAA GCT TGC TTC TाT GCT & \multirow[t]{2}{*}{54} & \multirow[t]{2}{*}{ [45] } \\
\hline & ECP620R: GAG CCC GGG GAT TTC ACA T & & \\
\hline \multirow[t]{2}{*}{ †SLT-I (614 bp) } & VT1 (SLTI-F): ACA CTG GAT GAT CTC AGT GG & \multirow[t]{2}{*}{55} & \multirow[t]{4}{*}{ [44] } \\
\hline & VT2 (SLTI-R): CTG AAT CCC CCT CCA TTA TG & & \\
\hline \multirow[t]{2}{*}{ +SLT-II (779 bp) } & VT3 (SLTII-F): CCA TGA CAA CGG ACA GCA GTT & \multirow[t]{2}{*}{55} & \\
\hline & VT4 (SLTII-R): CCT GTC AAC TGA GCA CTT T & & \\
\hline $16 \mathrm{~S}$ rDNA Sequencing & 616V: AGA GTT TGA TYM TGG CTC & 52 & \multirow[t]{3}{*}[46]{} \\
\hline \multirow[t]{2}{*}{$(\sim 1500 \mathrm{bp})$} & 630R: AAG GAG GTG GAT CCA RCC & & \\
\hline & CAKAAAGGAGGTGGATCC & & \\
\hline \multirow[t]{2}{*}{ Random Primer for RAPD } & DAF4: CGG CAG CGC C & 35 & [47] \\
\hline & M13V: GTT TTC CCA GTC ACG ACG TTG & 35 & [48] \\
\hline \multirow[t]{3}{*}{ Universal Primers } & HDA1: ACT CCT ACG GGA GGC AGC AG & 52 & \multirow[t]{3}{*}[49]{} \\
\hline & HDA2: GTA TTA CCG CGG CTG CTG GCA & & \\
\hline & $\begin{array}{l}\text { HDA1 + GC: CGC CCG GGG CGC GCC CCG GGC GGG GCG } \\
\text { GGG GGC ACG GGG GGA CTC CTA CGG GAG GCA GCA G }\end{array}$ & & \\
\hline \multirow[t]{2}{*}{ TA Cloning } & M13Forward (-20): GTA AAA CGA CGG CCA G & 55 & \multirow[t]{2}{*}[50]{} \\
\hline & M13Reverse: CAG GAA ACA GCT ATG AC & & \\
\hline †Pediocin Structural Gene pedA (100bp) & pedA2RTF: GGC CAA TAT CAT TGG TGG TA & 60 & [25] \\
\hline & pedA2RTR: ATT GAT TAT GCA AGT GGT AGC C & & \\
\hline & TqM-pedA: FAM-ACT TGT GGC AAA CAT TCC TGC & & \\
\hline & TCT GTT GA-TAMRA & & \\
\hline †Total Bacteria (727 bp) & TotalBac-F785: GGA TTA GAT ACC CTG GTA GTC & 52 & {$[51-53]$} \\
\hline & TotalBac-R1512r: TAC CTT GTT ACG ACT T & & \\
\hline & $\begin{array}{l}\text { TaqMan 1400r Probe: 6-FAM-TGA CGG GCG GTG TGT } \\
\text { ACA AGG C-TAMRA }\end{array}$ & & \\
\hline
\end{tabular}

control (Millipore Corporation, Bedford, Massachusetts, United States). The PCR program comprised of an initial denaturation step at $94^{\circ} \mathrm{C}$ for 3 minutes, followed by 5 cycles of denaturation, annealing and extension steps at $94^{\circ} \mathrm{C}$ for 3 minutes, $35^{\circ} \mathrm{C}$ for 5 minutes, and $72^{\circ} \mathrm{C}$ for 5 minutes. An additional 32 cycles of denaturation, annealing and extension steps were also performed at $94^{\circ} \mathrm{C}$ for 1 minute, $35^{\circ} \mathrm{C}$ for 2 minutes, $72^{\circ} \mathrm{C}$ for 3 minutes, followed by a final extension step at $72^{\circ} \mathrm{C}$ for 7 minutes. RAPD PCR products were electrophoresed in a $1.5 \%$ agarose gel with $0.5 \mathrm{x}$ TBE buffer $\left(45 \mathrm{mmol} \mathrm{L}^{-1}\right.$ Tris base, $45 \mathrm{mmol} \mathrm{L}^{-1}$ boric acid, $1 \mathrm{mM}$ EDTA, $\mathrm{pH}$ 8.0); isolates from the same animal were electrophoresed on the same gel. A 2-log molecular size marker (New England Biolabs, Pickering, Canada) was included on all gels.

\section{Partial 16S ribosomal rRNA gene amplification and sequencing}

Isolates differing in origin or RAPD pattern were identified by partial sequencing of $16 \mathrm{~S}$ rRNA genes. PCR reaction was performed in a master mix with a final volume of $50 \mu \mathrm{L}$ containing $1.5 \mathrm{U}$ Taq DNA Polymerase 
(Invitrogen), $5 \mu \mathrm{L}$ of $10 \mathrm{X}$ PCR Reaction Buffer (Invitrogen), $1.5 \mu \mathrm{L}$ of $25 \mathrm{mmol} \mathrm{L}^{-1} \mathrm{MgCl}_{2}$ (Invitrogen), $25 \mathrm{pmol}$ of universal bacterial primers $616 \mathrm{~V}$ and 630R (Table 2), $1 \mu \mathrm{L}$ of $10 \mathrm{mmol} \mathrm{L}^{-1} \mathrm{dNTP}$, and $1 \mu \mathrm{L}$ of template DNA. PCR product was electrophoresed in $1.0 \%(\mathrm{w} / \mathrm{v})$ agarose gel, with a 2-log ladder (New England Biolabs). All sequencing data were obtained from sequencing services provided by Macrogen (Rockville, USA). The $16 \mathrm{~S}$ rRNA gene sequences of isolates were compared with $16 \mathrm{~S}$ rRNA gene sequences of type strains in the Ribosomal Project Database Project II (RDP-II; Michigan State University, East Lansing, USA, http://rdp.cme.msu.edu).

\section{Identification of $E$. coli with species-specific PCR and API 20E test system}

PCR amplification of the hypervariable regions of the $E$. coli $16 \mathrm{~S}$ rRNA gene used primers described by Sabat et al. [45]. The PCR reaction mix (final volume $50 \mu \mathrm{L}$ ) consisted of $1.25 \mathrm{U}$ Taq DNA Polymerase (Invitrogen), $5 \mu \mathrm{L}$ of 10X PCR Reaction Buffer (Invitrogen), $1.5 \mu \mathrm{L}$ of $25 \mathrm{mmol} \mathrm{L}^{-1} \mathrm{MgCl}_{2}$ (Invitrogen), $100 \mathrm{pmol}$ of ECP79F and ECP620R (Table 2), $1 \mu \mathrm{L}$ of $10 \mathrm{mmol} \mathrm{L}^{-1} \mathrm{dNTP}$, and $1.5 \mu \mathrm{L}$ of template DNA. Reference strains used as positive and negative controls are listed in Table 3. The API 20E test system (bioMérieux, Saint Laurent, Canada) was used to confirm identification to the species level. PCR-based detection of Shiga-like toxin producing $E$. coli (STEC) was conducted with $50 \mu \mathrm{L}$ reaction mixes that contained 1.25 U Taq DNA Polymerase (Invitrogen), $5 \mu \mathrm{L}$ of 10X PCR Reaction Buffer (Invitrogen), 1.5 $\mu \mathrm{L}$ of $25 \mathrm{mmol} \mathrm{L}^{-1} \mathrm{MgCl}_{2}$ (Invitrogen), $1 \mu \mathrm{L}$ of $10 \mathrm{mmol}$ $\mathrm{L}^{-1}$ dNTP (Invitrogen), $25 \mathrm{pmol}$ SLTI-F and SLTI-R (Table 2), or 25 pmol SLTII-F and 25 pmol SLTII-R. Positive controls are listed in Table 3.

Table 3 Reference strains used in the study

\begin{tabular}{|c|c|}
\hline Strain & Description \\
\hline $\begin{array}{l}\text { Lactobacillus } \\
\text { plantarum FUA3099 }\end{array}$ & Positive control for RAPD with M13V primer \\
\hline $\begin{array}{l}\text { Shigella boydii } \\
\text { ATCC } 4388\end{array}$ & \multirow[t]{3}{*}{$\begin{array}{l}\text { Negative control for species specific PCR of } E \text {. } \\
\text { coli } 165 \text { rRNA gene }\end{array}$} \\
\hline $\begin{array}{l}\text { Shigella dysenteriae } \\
\text { ATCC188 }\end{array}$ & \\
\hline $\begin{array}{l}\text { Shigella flexneri } \\
\text { ATCC62 }\end{array}$ & \\
\hline $\begin{array}{l}\text { E. coli O157:H7 } \\
\text { ATCC } 43888\end{array}$ & $\begin{array}{l}\text { Positive control for species specific PCR of E. coll } \\
16 S \text { rRNA gene }\end{array}$ \\
\hline $\begin{array}{l}\text { E. coli } 0157: \mathrm{H7} \\
\text { ATCC43889 }\end{array}$ & SLT-II positive control \\
\hline $\begin{array}{l}\text { E. coli O157:H7 } \\
\text { ATCC } 43890\end{array}$ & SLT-I positive control \\
\hline $\begin{array}{l}\text { Pediococcus acidilactici } \\
\text { FUA3072 }\end{array}$ & $\begin{array}{l}\text { Bacteriocin-producing strain expressing the } \\
\text { pediocin AcH/PA-1 operon }\end{array}$ \\
\hline $\begin{array}{l}\text { Listeria innocua } \\
\text { ATCC } 33090\end{array}$ & $\begin{array}{l}\text { Indicator strains used in deferred inhibition } \\
\text { assay for bacteriocins detection }\end{array}$ \\
\hline
\end{tabular}

Detection of bacteriocin production by Lactobacillus spp. and Pediococcus spp

Lactobacillus species and Pediococcus species were initially screened for production of pediocin AcH by PCR amplification of the pediocin $\mathrm{AcH}$ immunity gene. The gene amplification was performed with $50 \mu \mathrm{L}$ reaction mixes that contained $1.5 \mathrm{U}$ Taq DNA polymerase (Invitrogen), $5 \mu \mathrm{L}$ of 10X PCR reaction buffer (Invitrogen), $1.5 \mu \mathrm{L}$ of $25 \mathrm{mM} \mathrm{MgCl}_{2}$ (Invitrogen), $1 \mu \mathrm{L}$ of $10 \mathrm{mM}$ dNTP (Invitrogen), $2 \mu \mathrm{L}$ of template DNA, 25 pmol of primers Pediocin-for (TCA ATA ATG GAG CTA TGG) and Pediocin-rev (ACC AGT CTC CAG AAT ATC TAA). Bacteriocin production by lactic acid bacteria was determined with bacteriocins screening medium as described [54]. Overnight cultures of test strains were prepared in MRS broth that contained $2 \mathrm{~g} \mathrm{~L}^{-1}$ glucose. Test strains used in this study included Lactobacillus sakei FUA3089 as well as Ped. acidilactici FUA3138 and FUA3140. MRS plates with 2 g glucose $\mathrm{L}^{-1}$ were spotted with $3 \mu \mathrm{L}$ of each overnight culture and the plates were incubated overnight under anaerobic conditions at $37^{\circ} \mathrm{C}$. Ped. acidilactici FUA3072 was used as reference strain. Bacteriocin formation of this strain was previously characterized by sequencing of the pediocin operon, quantification of the expression of genes of the pediocin operon, and deferred inhibition assay (data not shown).

Cultures of indicator strains (Table 3) grown in overnight MRS broth with $2 \mathrm{~g} \mathrm{~L}^{-1}$ glucose were used to inoculate MRS soft agar at an inoculation level of $1 \%$ and the soft agar was overlayered over the MRS plates with test strains. Indicator strains included E. coli FUA1036, E. coli FUA1063, E. coli FUA1064, Listeria innocua ATCC33090, and Enterococcus facaelis FUA3141.

The deferred inhibition assay was repeated with the addition of $20 \mathrm{~g} \mathrm{~L}^{-1}$ proteinase $\mathrm{K}$ in $100 \mathrm{mmol} \mathrm{L}^{-1}$ Tris-Cl, $\mathrm{pH}$ 8.5, which was spotted adjacent to test strain colonies and plates were incubated for four hours at $55^{\circ} \mathrm{C}$ to maximize proteinase activity before overlayering was conducted.

\section{Identification of library clones via sequencing}

PCR-DGGE analysis was initially carried out characterise bovine vaginal microbiota by a culture-independent approach. The DNA concentration of samples from healthy cows, however, was below the detection limit of PCR-DGGE analysis and DGGE patterns could be obtained only for two samples from animals \#2373 \#2409 (data not shown). Total bacterial DNA was isolated from these two vaginal swab samples via both phenol chloroform extraction and Wizard MagneSil ${ }^{\circledR} \mathrm{Tfx}^{\mathrm{TM}}$ System (Promega). Nested PCR was conducted to maximize DNA amplification by amplifying with $616 \mathrm{~V}$ and 630R primers prior to amplification with HDA primers (Table 2). PCR products that were amplified with 
HDA primers were cloned into a pCR 2.1-TOPO vector using the TOPO TA Cloning ${ }^{\circledR}$ Kit (Invitrogen) according to manufacturer's instructions. The Promega's Wizard ${ }^{\circledR}$ Plus SV A clone library was constructed using PCR products that were amplified with HDA primers, which were then cloned into a pCR 2.1-TOPO vector, using the TOPO TA Cloning ${ }^{\circledR}$ Kit (Invitrogen) according to manufacturer's instructions. The Promega's Wizard $^{\circledR}$ Plus SV Minipreps DNA Purification System was used for plasmid isolation. To confirm the cloning of the inserts, sequencing of the amplified insert was performed according to the Invitrogen TOPO TA Cloning ${ }^{\circledR}$ Kit manual.

\section{Quantitative PCR}

Quantitative PCR was conducted with vaginal mucus samples collected from ten cows, using syringes fitted with an approximately $30 \mathrm{~cm}$ long collection tube. Samples from 10 animals that developed metritis after calving were randomly selected from samples of a larger cohort of animals. Total bacterial DNA was extracted using the Wizard MagneSil ${ }^{\circledR} \mathrm{Tfx}^{\mathrm{TM}}$ System (Promega) and DNA concentrations were measured using the NanoDrop spectrophotometer system ND-1000, software version 3.3.0 (Thermo Fisher Scientific Inc., Wilmington, USA). All dagger-marked primer pairs that are listed in Table 2 were used in the preparation of standards and qPCR analyses. Standards were prepared using purified PCR products, which were serially diluted ten-fold. Diluted standards $\left(10^{-3}\right.$ to $\left.10^{-8}\right)$ were used to generate standard curves. TaqMan probes were used for the pedA gene and the total bacteria qPCR experiments. In both cases, each probe was labelled with 5'-FAM and 3'-TAMRA as fluorescent reporter dye and quencher respectively. The total reaction volume was set to $25 \mu \mathrm{L}$, which contained $12.5 \mu \mathrm{L}$ TaqMan Universal PCR Master Mix (Applied Biosystems), $2.5 \mu \mathrm{L}$ of template DNA extracted from vaginal mucus and $5 \mu \mathrm{mol} \mathrm{\textrm {L } ^ { - 1 }}$ of each primer (Table 2), and $0.2 \mu \mathrm{mol} \mathrm{L}^{-1}$ of the TaqMan probe. SYBR green assays were used for all remaining targetgroup primer pairs. The total reaction was also set at $25 \mu \mathrm{L}$ containing $12.5 \mu \mathrm{L}$ Fast SYBR Green Master Mix (Applied Biosystems), $1 \mu \mathrm{mol} \mathrm{L}{ }^{-1}$ primer, and $1 \mu \mathrm{L}$ DNA template. Amplification conditions generally followed an initial denaturation at $95^{\circ} \mathrm{C}$ for 5 min for 1 cycle; 40 cycles of denaturation at $95^{\circ} \mathrm{C}$ for $30 \mathrm{sec}$, annealing with listed annealing temperatures in Table 2 for $1 \mathrm{~min}$, and extension at $72^{\circ} \mathrm{C}$ for $2 \mathrm{~min}$. Quantitative PCR was executed using a 7500 Fast Real-Time PCR System (Applied Biosystems, Foster City, CA, USA). Reactions were performed in triplicates in MicroAmp Fast Optical 96-well reaction plates, sealed with MicroAmp Optical Adhesive Film (Applied Biosystems).

\section{Statistical analysis}

Results were analyzed using the general linear models procedure of SAS (Release 9.2, SAS Institute, Inc., Cary, NC, USA). The mathematical model used one animal as experimental unit and included the type of bacteria as the dependent variable and tested for differences in the least square means of log rDNA or DNA copy numbers for each target group between the two periods (i.e., prepartum versus post-partum).

\section{Gene accession numbers of 16S rRNA gene sequences obtained in this study}

Sequences of $16 \mathrm{~S}$ rRNA genes of isolates obtained in this study were deposited in GenBank ${ }^{\circledR}$ with the following accession numbers: FUA3086 (GQ222397), FUA3087 (GQ222398), FUA3088 (GQ222399), FUA3089

(GQ222408), FUA1167 (GQ205673), FUA1035

(GQ222390), FUA1037 (GQ222410), FUA3137

(GQ222393), FUA3140 (GQ222392), FUA3141

(GQ222407), FUA3226 (GQ222394), FUA3136

(GQ205672), FUA1062 (GQ222401), FUA2027

(GQ205674), FUA2028 (GQ222400), FUA3251

(GQ222395), FUA1046 (GQ222387), FUA3135

(GQ222404), FUA2023 (GQ205670), FUA2024

(GQ205671), FUA1036, (GQ222389), FUA3139

(GQ222406), FUA1063 (GQ222403), FUA3227

(GQ205669), FUA3138 (GQ222409), FUA1049

(GQ222388), FUA1070 (GQ222391), FUA1064

(GQ222405), FUA3180 (GQ222402), $\quad$ FUA2029

(GQ222396).

\section{Competing interests}

The authors declare that they have no competing interests.

\section{Authors' contributions}

YW, BA, DA and MGG designed research; DA collected samples and diagnosed metritis in post-partum animals; YW assisted with sample collections and conducted the research; YW, DA and MGG analyzed data; YW, BA, DA and MGG wrote the paper; and MGG had primary responsibility for final content. All authors read and approved the final manuscript.

\section{Acknowledgements}

We acknowledge Judith van der Lelij and Marleen Roes for their excellent support and contribution to our research. The Alberta Livestock Industry Development Fund, Alberta Milk, and the Canada Research Chairs program are acknowledged for financial support.

\section{Author details}

${ }^{1}$ Department of Agricultural, University of Alberta, Food and Nutritional Science, 4-10 Ag/For Centre, Edmonton, AB T6G 2P5, Canada. ${ }^{2}$ Alberta Agriculture and Rural Development, Agriculture Research Division, Edmonton, AB T6H 5T6, Canada.

Received: 2 March 2012 Accepted: 21 January 2013

Published: 29 January 2013

\section{References}

1. Sheldon IM, Lewis GS, LeBlanc S, Gilbert RO: Defining postpartum uterine disease in cattle. Theriogenology 2006, 65:1516-1530.

2. Ross JDC: An update on pelvic inflammatory disease. Sex Transm Infect 2002, 78:18-19. 
3. Lewis GS: Symposium: Health problems of the postpartum cow. J Dairy Sci 1997, 80:984-994.

4. Coleman DA, Thayne W, Dailey RA: Factors affecting reproductive performance of dairy cows. J Dairy Sci 1985, 68:1793-1803.

5. Sheldon I, Dobson H: Postpartum uterine health in cattle. Anim Reprod Sci 2004, 82-83:295-306.

6. Sheldon IM, Noakes DE, Rycroft AN, Pfeiffer DU, Dobson H: Influence of uterine bacterial contamination after parturition on ovarian dominant follicle selection and follicle growth and function in cattle. Reproduction 2002, 123:837-845.

7. Williams EJ, Fischer DP, Pfeiffer DU, England GCW, Noakes DE, Dobson $\mathrm{H}_{\text {, }}$ Sheldon IM: Clinical evaluation of postpartum vaginal mucus reflects uterine bacterial infection and the immune response in cattle. Theriogenology 2005, 63:102-117.

8. Williams EJ, Fischer DP, Noakes DE, England GCW, Rycroft A, Dobson H, Sheldon IM: The relationship between uterine pathogen growth density and ovarian function in the postpartum dairy cow. Theriogenology 2007, 68:549-559

9. Redondo-Lopez V, Cook RL, Sobel JD: Emerging role of lactobacilli in the control and maintenance of the vaginal bacterial microflora. Rev Infect Dis 1990, 12:856-872.

10. Vintiñi E, Ocaña V, Elena Nader-Macías M: Effect of lactobacilli administration in the vaginal tract of mice: evaluation of side effects and local immune response by local administration of selected strains. Methods Mol Biol 2004, 268:401-410.

11. Herthelius M, Gorbach SL, Möllby R, Nord CE, Pettersson L, Winberg J: Elimination of vaginal colonization with Escherichia coli by administration of indigenous flora. Infect Immun 1989, 57:2447-2451.

12. Charteris WP, Kelly PM, Morell L, Collins KJ: Antibacterial activity associated with Lactobacillus gasseri ATCC 9857from the human female genitourinary tract. World J Microbiol Biotechnol 2004, 17:615-625.

13. Eschenbach DA, Davick PR, Williams BL, Klebanoff SJ, Young-Smith K Critchlow CM, Holmes KK: Prevalence of hydrogen peroxide-producing Lactobacillus species in normal women and women with bacterial vaginosis. J Clin Microbiol 1989, 27:251-256.

14. Corr SC, Li Y, Riedel CU, O'Toole PW, Hill C, Gahan CGM: Bacteriocin production as a mechanism for the antiinfective activity of Lactobacillus salivarius UCC118. Proc Natl Acad Sci 2007, 104:7617-7621.

15. Otero C, Silva De Ruiz C, Ibañez R, Wilde OR, De Ruiz Holgado AAP, Nader-Macias ME: Lactobacilli and enterococci isolated from the bovine vagina during the estrous cycle. Anaerobe 1999, 5:305-307.

16. Otero C, Saavedra L, Silva De Ruiz C, Wilde O, Holgado AR, Nader-Macías ME: Vaginal bacterial microflora modifications during the growth of healthy cows. Lett. Appl. Microbiol. 2000, 31:251-254.

17. Ambrose JD, Pattabiraman SR, Venkatesan RA: Types and incidence of aerobic bacteria in different puerperal conditions in bovines. Cheiron 1986, 15:176-179.

18. Christensen H, Nordentoft S, Olsen JE: Phylogenetic relationships of Salmonella based on rRNA sequences. Int. J. Syst. Bacteriol. 1998, 48(Pt 2):605-610.

19. Wani SA, Bhat MA, Samanta I, Nishikawa Y, Buchh AS: Isolation and characterization of Shiga toxin-producing Escherichia coli (STEC) and enteropathogenic Escherichia coli (EPEC) from calves and lambs with diarrhoea in India. Letters in Applied microbiology 2003, 37:121-6.

20. Williams EJ, Sibley K, Miller AN, Lane EA, Fishwick J, Nash DM, Herath S, England GCW, Dobson H, Sheldon IM: The effect of Escherichia col lipopolysaccharide and tumour necrosis factor alpha on ovarian function. Am J Reprod Immunol 2008, 60:462-473.

21. Eijsink VGH, Axelsson L, Diep DB, Håvarstein LS, Holo H, Nes IF: Production of class II bacteriocins by lactic acid bacteria; an example of biological warfare and communication. Antonie Van Leeuwenhoek 2002, 81:639-654.

22. Hudson JA, Cai Y, Corner RJ, Morvan B, Joblin KN: Identification and enumeration of oleic acid and linoleic acid hydrating bacteria in the rumen of sheep and cows. J App/ Microbiol 2000, 88:286-292.

23. Juven BJ, Meinersmann RJ, Stern NJ: Antagonistic effects of lactobacilli and pediococci to control intestinal colonization by human enteropathogens in live poultry. J App/ Bacteriol 1991, 70:95-103.

24. Kurzak P, Ehrmann MA, Vogel RF: Diversity of lactic acid bacteria associated with ducks. Syst Appl Microbiol 1998, 21:588-592.

25. Mathys S, von Ah U, Lacroix C, Staub E, Mini R, Cereghetti T, Meile L: Detection of the pediocin gene pedA in strains from human faeces by real-time PCR and characterization of Pediococcus acidilactici UVA1. BMC Biotechnol 2007, 7:55.

26. Bennik M, Smid EJ, Gorris L: Vegetable-associated Pediococcus parvulus produces pediocin PA-1. Appl Environ Microbiol 1997, 63:2074-2076.

27. Ennahar S, Aoude-Werner D, Sorokine O, Van Dorsselaer A, Bringel F, Hubert JC, Hasselmann C: Production of pediocin AcH by Lactobacillus plantarum WHE 92 isolated from cheese. Appl Environ Microbiol 1996, 62:4381-4387.

28. Gonzalez CF, Kunka BS: Plasmid-associated bacteriocin production and sucrose fermentation in Pediococcus acidilactici. Appl Environ Microbiol 1987, 53:2534-2538.

29. Ray SK, Johnson MC, Ray B: Bacteriocin plasmids of Pediococcus acidilactici. J Ind Microbiol Biotechnol 1989, 4:163-171.

30. Marugg JD, Gonzalez CF, Kunka BS, Ledeboer AM, Pucci MJ, Toonen MY, Walker SA, Zoetmulder LC, Vandenbergh PA: Cloning, expression, and nucleotide sequence of genes involved in production of pediocin PA-1, and bacteriocin from Pediococcus acidilactici PAC1.0. Appl. Environ. Microbiol. 1992, 58:2360-2367.

31. Hammes WP, Hertel C: New developments in meat starter cultures. Meat Sci. 1998, 49S1:S125-138.

32. Dobson A, Cotter PD, Ross RP, Hill C: Bacteriocin production: a probiotic trait? Appl Environ Microbiol 2012, 78:1-6.

33. Juarez Tomás MS, Bru E, Wiese B, de Ruiz Holgado AAP, Nader-Macías ME: Influence of $\mathrm{pH}$, temperature and culture media on the growth and bacteriocin production by vaginal Lactobacillus salivarius CRL 1328. J Appl Microbiol 2002, 93:714-724.

34. Sobel: Is there a protective role for vaginal flora? Curr Infect Dis Rep 1999, 1:379-383.

35. Alpay-Karaoğlu S, Aydin F, Kiliç S, Kiliç A: Antimicrobial activity and characteristics of bacteriocins produced by vaginal lactobacilli. Turk J Med Sci 2002, 33:7-12.

36. Sobel JD, Chaim W: Vaginal microbiology of women with acute recurrent vulvovaginal candidiasis. J Clin Microbiol 1996, 34:2497-2499.

37. Stolz P, Böcker G, Hammes WP: Utilisation of maltose and glucose by lactobacilli isolated from sourdough. FEMS Microbiol Lett 1993, 109:237-242.

38. Sambrook J, Fritsch E, Maniatis T: Molecular cloning: a laboratory manual. 2nd edition. Cold Spring: Cold Spring Harbor Laboratory Press; 1989.

39. Heilig HGHJ, Zoetendal EG, Vaughan EE, Marteau P, Akkermans ADL, de Vos WM: Molecular diversity of Lactobacillus spp. and other lactic acid bacteria in the human intestine as determined by specific amplification of 16 S ribosomal DNA. Appl Environ Microbiol 2002, 68:114-123.

40. Walter J, Tannock GW, Tilsala-Timisjarvi A, Rodtong S, Loach DM, Munro K, Alatossava T: Detection and identification of gastrointestinal Lactobacillus species by using denaturing gradient gel electrophoresis and species-specific PCR primers. App/ Environ Microbiol 2000, 66:297-303.

41. Rinttilä T, Kassinen A, Malinen E, Krogius L, Palva A: Development of an extensive set of $16 \mathrm{~S}$ rDNA-targeted primers for quantification of pathogenic and indigenous bacteria in faecal samples by real-time PCR. J Appl Microbiol 2004, 97:1166-1177.

42. Bartosch S, Fite A, Macfarlane GT, McMurdo MET: Characterization of bacterial communities in feces from healthy elderly volunteers and hospitalized elderly patients by using real-time PCR and effects of antibiotic treatment on the fecal microbiota. Appl Environ Microbiol 2004, 70:3575-3581

43. Martineau F, Picard FJ, Ke D, Paradis S, Roy PH, Ouellette M, Bergeron MG: Development of a PCR assay for identification of staphylococci at genus and species levels. J Clin Microbio/ 2001, 39:2541-2547.

44. Garbeva P, van Veen JA, van Elsas JD: Predominant Bacillus spp. in agricultural soil under different management regimes detected via PCR-DGGE. Microb Ecol 2003, 45:302-316.

45. Sabat G, Rose R, Hickey WJ, Harkin JM: Selective sensitive method for PCR amplification of Escherichia coli 16S rRNA genes in soil. Appl Environ Microbiol 2000, 66:844-849.

46. Juretschko S, Timmermann G, Schmid M, Schleifer KH, Pommerening-Roser A, Koops HP, Wagner M: Combined molecular and conventional analyses of nitrifying bacterium diversity in activated sludge: Nitrosococcus mobilis and Nitrospira-like bacteria as dominant populations. Appl Environ Microbiol 1998, 64:3042-3051.

47. Vogel L, van Oorschot E, Maas HME, Minderhoud B, Dijkshoorn L: Epidemiologic typing of Escherichia coli using RAPD analysis, ribotyping and serotyping. Clin Microbiol Infect 2000, 6:82-87. 
48. Hamad SH, Dieng MC, Ehrmann MA, Vogel RF: Characterization of the bacterial flora of Sudanese sorghum flour and sorghum sourdough. J Appl Microbiol 1997, 83:764-770.

49. Walter J, Hertel C, Tannock GW, Lis CM, Munro K, Hammes WP: Detection of Lactobacillus, Pediococcus, Leuconostoc, and Weissella species in human feces by using group-specific PCR primers and denaturing gradient gel electrophoresis. Appl Environ Microbiol 2001, 67:2578-2585.

50. Yanisch-Perron C, Vieira J, Messing J: Improved M13 phage cloning vectors and host strains: nucleotide sequences of the $\mathrm{M} 13 \mathrm{mpl} 8$ and pUC19 vectors. Gene 1985, 33:103-119.

51. Lyons SR, Griffen AL, Leys EJ: Quantitative real-time PCR for Porphyromonas gingivalis and total bacteria. J Clin Microbiol 2000, 38:2362-2365.

52. Fry NK, Fredrickson JK, Fishbain S, Wagner M, Stahl DA: Population structure of microbial communities associated with two deep, anaerobic alkaline aquifers. Appl Environ Microbiol 1997, 63:1498-1504.

53. Greisen K, Loeffelholz M, Purohit A, Leong D: PCR primers and probes for the $16 \mathrm{~S}$ rRNA gene of most species of pathogenic bacteria, including bacteria found in cerebrospinal fluid. J Clin Microbiol 1994, 32:335-351.

54. Tichaczek PS, Nissen-Meyer J, Nes IF, Vogel RF, Hammes WP: Characterization of the bacteriocins curvacin A from Lactobacillus curvatus LTH1174 and sakacin P from L. sake LTH673. System Appl Microbiol 1992, 15:460-468.

doi:10.1186/1471-2180-13-19

Cite this article as: Wang et al:: Characterisation of the bacterial microbiota of the vagina of dairy cows and isolation of pediocinproducing Pediococcus acidilactici. BMC Microbiology 2013 13:19.

\section{Submit your next manuscript to BioMed Central and take full advantage of:}

- Convenient online submission

- Thorough peer review

- No space constraints or color figure charges

- Immediate publication on acceptance

- Inclusion in PubMed, CAS, Scopus and Google Scholar

- Research which is freely available for redistribution 